\section{MUHASEBE MESLEK \\ MENSUPLARININ ÖFKE VE STRES ÍLIŞKISII ÜZERİNE BİR ARAŞTIRMA (ELAZIĞ İLİ ÖRNEĞİ)}

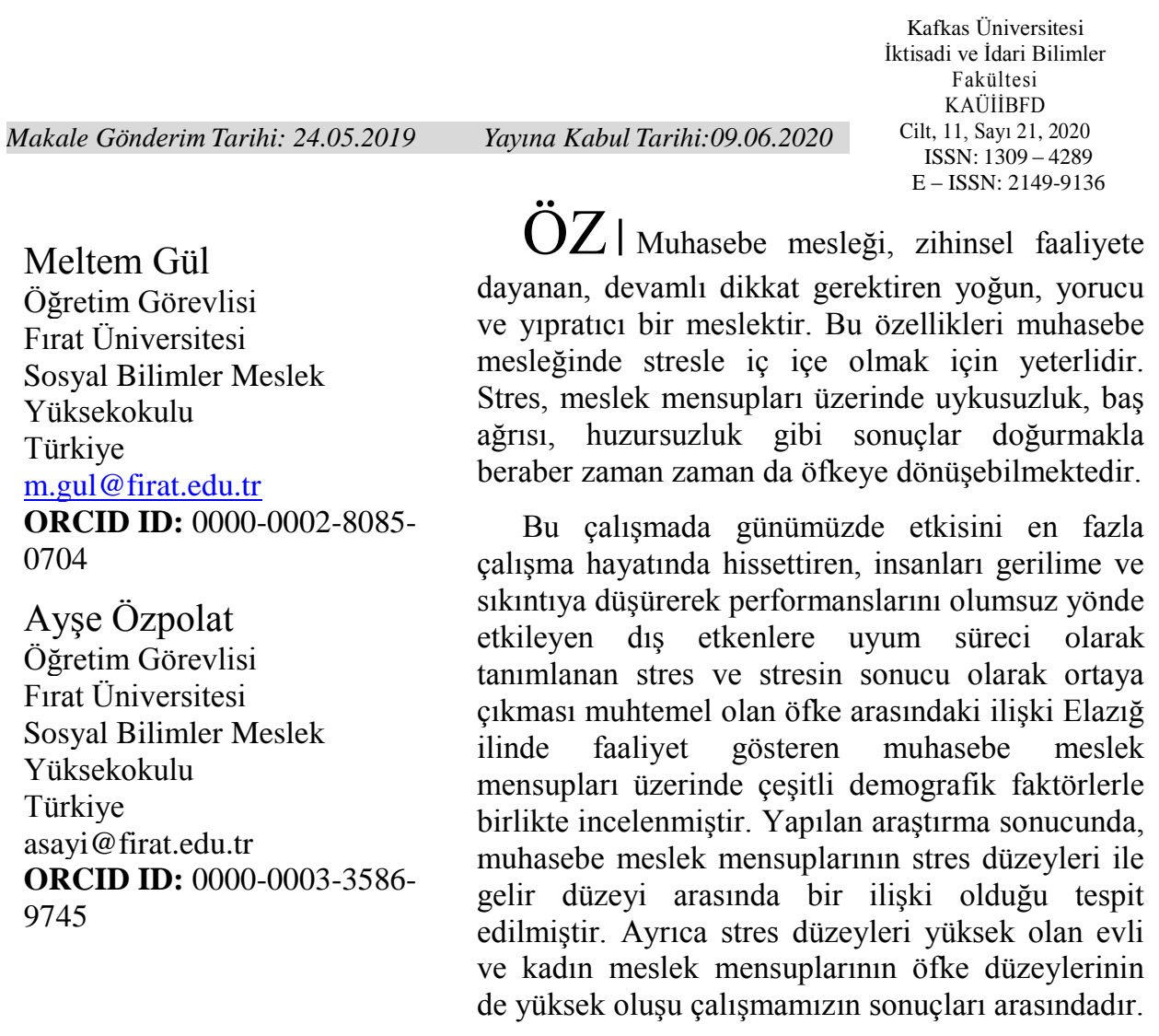

Anahtar Kelimeler: Muhasebe Meslek Mensuplarl, Stres, Öfke

JEL Kodu: M40, M49, I3I

Alanı: İ̧sletme

Türü: Araştırma

DOI: 10.36543/kauiibfd.2020.010

Atıfta bulunmak için: Gül, M., Özpolat, A. (2020). Muhasebe meslek mensuplarının öfke ve stres ilişkisi üzerine bir araştırma (Elazığ ili örneği). KAÜIİBFD, 11(21), 203-224. 


\section{AN INVESTIGATION ON THE RELATIONSHIP BETWEEN ANGER AND STRESS OF ACCOUNTING PROFESSION (THE CASE OF ELAZÍG PROVINCE)}

\section{Article Submission Date: 24.05.2019}

Accepted Date: 09.06.2020

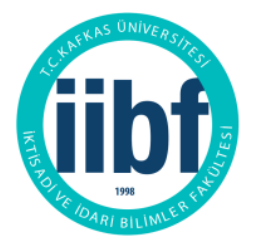

Kafkas Üniversity Economics and Administrative Sciences Faculty KAUJEASF

Vol. 11, Issue 21, 2020 ISSN: $1309-4289$ E - ISSN: 2149-9136

\author{
Meltem GÜL \\ Lecturer \\ Furat University \\ Vocational School of Social \\ Sciences \\ Turkey \\ m.gul@ firat.edu.tr
}

ORCID ID: 0000-0002-80850704

\section{Ayşe ÖZPOLAT}

Lecturer

Firat University

Vocational School of Social

Sciences

Turkey

asayi@ firat.edu.tr

ORCID ID: 0000-0003-3586-

9745

\section{ABSTRACT $\mid$ The profession of} accounting is a busy, tiring and backbreaking occupation basing on mental activity, demanding permanent care. These characteristics of accounting are sufficient for living together with stress. While stress may cause insomnia, headache, uneasiness on the members of a profession, it may also sometimes turn into anger.

In this study, the relationship between stress, which makes feel its effect mostly on working life today, and defined as the orientation period to the external factors affecting the performance of people negatively by leading to tension and distress, and anger, which is possible to emerge as a result of stress, was investigated concerning the members of accounting profession working in Elazig through several factors. As a result of the research, it has been determined that there is a relationship between the stress levels of the professional accountants and the income level. One of the results of our study showed that married and woman members of the profession with high-stress levels had also high levels of anger.

Keywords: Members of Accounting Profession, Stress, Anger

Jel codes: M40, M49, I31

Scope: Business

Type: Research

Cite this Paper: Gül, M., Özpolat, A. (2020). An investigation on the relationship between anger and stress of members of accounting profession (the case of elazig province). KAUJEASF, $11(21), 203-224$ 


\section{Gİiș}

İş hayatının kaçınılmaz gerçeklerinden biri strestir. Muhasebe meslek mensupları gerek iş yoğunluklarının fazla olması, gerekse de düzenlemiş oldukları mali tabloların doğru olması zorunluluğu nedeniyle yoğun bir stres altında mesleklerini icra etmektedirler. $\mathrm{Bu}$ yoğun stres meslek mensupları üzerinde zaman zaman öfkeye sebep olmaktadır. Meslek mensuplarını stresli ve öfkeli biri olmaya iten sebeplerin başında müşteri sayısından ve mevzuattan kaynaklanan iş yükü fazlalığı, işlemleri yetiştirmede yaşanan zaman baskısı, uzun ve belirsiz çalışma saatleri, müşterilerle iletişimden kaynaklanan sorunlar, işin aşırı dikkat gerektirmesi, bilgisayar sistemindeki arızalar, bilgisayar ile çalışma zorunluluğu, sürekli çalan telefonlar, dengesiz iş yükü dağılımı, sosyal etkinliklere, aileye özellikle de çocuklara yeterince zaman ayrılamaması gibi etkenler gelmektedir. Bu durum iş hayatındaki verimliliği azaltmaktadır.

Bu noktadan hareketle bu çalışmada, Elazığ ilinde faaliyet gösteren muhasebe meslek mensuplarının öfke ve stres ilişkisi incelenmiştir. Çalışma üç bölümden oluşmaktadır. Birinci bölümde stres ve öfke faktörleri, tetikleyicileri ve sonuçları üzerinde durulmuştur. İkinci bölümde konuyla ilgili literatür taraması yapılmıştır. Üçüncü bölümde ise stres ve öfke ilişkisi çeşitli istatiksel yöntemlerle analiz edilmiştir.

\section{STRES VE ÖFKE (FAKTÖRLER, TETIKLEYICILIER, SONUÇLAR)}

İnsanlar geçmişten günümüze mutlu olabilmek ve mutlu bir yaşam sürdürebilmek için çaba göstermiş ve tüm hayatlarını bu uğurda harcamışlardır. Mutluluk kişinin yaşamın bilişsel ve duyuşsal yönleriyle değerlendirilmesi sonucunda olumlu duyguların daha fazla yaşaması olarak görülebilir (Altan \& Çivitçi, 2017, s. 309). Günümüzdeki çalışma koşulları insanın günlük zamanının oldukça önemli bir kısmını işgal etmekte ve olumlu ya da olumsuz, fonksiyonel ve disfonksiyonel duyguları birlikte barındırmaktadır. Disfonksiyonel yani işgörenlerde gerilime neden olan olumsuz duygular bir çok faktörlerle oluşmakta fakat işyerleri ve çalışma koşulları bu duyguları absorbe edecek ortamların oluşumunu da engellemektedir.

Olumsuz ve yıkıcı duygu olarak görülen öfke, mutluluk, üzüntü, korku ve nefret ile birlikte insanın beş temel duygusundan biridir. Engellenme, tehdit edilme, yoksun bırakma ya da kasıtlı kötü muamele gördüğü, engellemelere maruz 
kaldığ1 algısı, kişiliği tehdit eden dış kaynaklı saldırılar, kişinin düşünce yapıs1, olayları ve kendini algılama şekli, mükemmeliyetçi olması, yüksek kabul edilme ve onaylanma ihtiyacı, öfke içeren davranışların cezalandırılması hayal kırıklığı, ekonomik, sosyal ve kişiler arası problemler gibi durumlarda hissedilmekte ve öfke kaynağına saldırgan davranışları içermektedir. Öfkenin sağlıksız dişa vurumu saldırganlık ve şiddete neden olmaktadır (Gönen, 2015, s. 47,48; Altan \& Çivitçi, 2017, s. 310). Öfke, yaşanma sıklığı ve yoğunluğu açısından ikiye ayrılmaktadır.

1.Durumsal Öfke: Kısa aralıklarla ortaya çıkmakta yoğunluğu ve şiddeti değişebilen duygusal ve fizyolojik bir duygusur. Durumsal öfkenin temelinde, amaca yönelmiş davranışın engellenmesi veya haksızlık karşısında yoğun gerginlik, sinirlilik, hiddet hali bulunmaktadır. Kişinin yaşadığı hayal kırıklıkları, acı çekme, incinme ve karşılanmamış beklentiler gibi süreçlerde bulunmaktadır. Genellikle kişide zamanla birikmiş olan ve ani bir biçimde bir yansıma olarak ortaya çıkmaktadır.

2.Sürekli Öfke: Öfkelenmeye eğilimli olma hali olan sürekli öfke, kişide çoğu zaman spontan bir tepki olarak bulunmaktadır. Kişinin çok sayıda durum ya da ortamı can sıkıcı ve engelleyici olarak algılaması sonucu ortaya çıkmaktadır. Sürekli öfke düzeyi yüksek kişiler öfkelerini kontrol etmekte zorlanırlar ve genellikle günlük olarak öfkeli bir ruh haline sahiptirler. Yapılan araştırmalar neticesinde süekli öfkeli olan kişiler kendi yaşamına ilişkin alg1 ve değerlemeleri genellikle olumsuz olabilmektedir. Sürekli öfke düzeyi yüksek kişiler, çoğu zaman kendilerini öfkelendiren şeyin ne olduğunu bilmedikleri ve öfkeli hallerini inkar edebilmektedirler (Altan \& Çivitçi, 2017, s. 310; Gönen, 2015, s. 51).

Öfke, düşmanlık ve saldırganlıktan daha basit, yoğunluğu hafif huzursuzluk veya can sıkıntısından, kızgınlık ve şiddete kadar uzanan durumları içermektedir. Saldırganlık ile dışa yönelik ifade biçimi olan öfke saldırganlığın itici gücüdür (Gönen, 2015, s. 47). Saldırgan davranışların sergilendiği öfkeli durumdaki kişi, kendi kendi ikna için yani kendi haklılığını çıkarmak için iç monoloğu yoğun bir şekilde kullanır. Bu durumdaki kişide öfke, olumsuz duygulardan üzüntünün aksine bireye enreji vererek coşkunluk hali oluşturur. Öfkeyle zihin haklılığını ilan eder ve kendini en ikna edici fikirlerle doldurur. Öfkelenme nedeni hakkında uzun düşünmeler öfkeyi haklı çıkaracak birçok sebep icat edebilir. Fakat öfkesi alevlenen kişi yine öfkesini bu ikna edici fikirlerle söndürmektedir. Öfke nedenine değişik açılardan bakmayı başaran kişi 
öfke durumundan çıabilir ve olumlu bir çerçeveden durumu yeniden analiz edebilir (Goleman, 2018, s. 205).

Öfkenin çıkış nedenlerinin kökeninde insanlar arası ilişki bulunmaktadır. Gündelik yaşam, iş yaşamıda dahil olmak üzere çıkar çatışmalarıyla, beklenti ve hayal kırıklarıyla örülüdür. İnsanların özellikle ömrünün üçte ikilik kısmının iş yaparak geçirdiği düşünüldüğünde, temel amaçların maddi ve manevi menfaat olmasından dolayı öfke sebepleri olarak iş yaşamı önemli sebepleri barındırdığ 1 söylenebilir. İnsanlar ekonomik etkinliklerini gerçekleştirirken öfke ve öfke ifadesi; iş yeri stresi, örgütün organizasyon yapısında ki bozukluklar, otokratik yönetim, iş yerinin koşulları, kişinin çalışma ortamındaki statüsü, örgütsel kararlara katılma ve karar vermede yetersizlik, yöneticilerin yetersizliği, örgütün demokratik olmayan, hiyerarşik, merkeziyetçi niteliği, varolan liderlik biçimi, rol karmaşası ve rol belirsizliği ve bireyin kişiliğinin etkileşimi ile ilişkisi sonucunda ortaya çıkmaktadır (Keskin, Gümüş, \& Engin, 2011, s. 200).

Örgüt içerisinde çalışmanın yapısı, çalışma zamanları, çalışmanın temposu örgüt içi fizyolojik faktörler veya bilişsel faktörler örgüt içi stres oluşturacak dinamikleri barındırmakla birlikte örgüt enformel yapısı itibariylede bir çok stres faktörünü barındırmaktadır. İş kaybetme olasılığı, çalışma zamanları, gelir düşüklügü, teknolojik değişim ve yetenek yitimi, gürültü, monotonluk, 1şıklandırmada ve havalandırma yetersizliği gibi bir çok olumsuz durumları barındırabilmektedir. Bunlara ilaveten çalışma yaşamı için elzem olan ve bir çok olumsuz durumun yaşanmasına temel olan duygu güven duygusudur. İş yerinde güvenin olmadığı ortamlarda iş görenler aşırı stresli, kaygılı ve endişeli bir psikolojiye sahip olabilirler (Tutar, 2014, s. 86).

Stres iş görenin uyum örgütsel sosyalizasyonun başarısız olmasına ve uyum sorunlarına, iş görenin bedensel ve ruhsal sağlığının bozulmasına ve verimin düşmesine neden olmaktadır. Öfke ve stres çoğunlukla aynı ortamlarda oluşmaktadır. yani stres faktörleri aynı zamanda öfke tetikleyicileridir. Hatta öfke gibi olumsuz duygular strese neden olmaktadır. Stres sonucunda ise yine öfke duygusu yaşanabilmektedir. Bir kısır döngü olarak strese neden olan koşullar olumsuz duygulara neden olurken bu duygular stres oluşturan ortamların oluşturucusudur.

Stres, sonucu önemli olmasına rağmen belli olmayan durum veya olguyla ilgili fırsat, zorlama ve istem karşısında kişinin yaşadığı durumdur. Aşırı ve çoğu zaman istenmeyen uyarılara ve çevreden gelen tehdit edici olaylara karşı kişide 
gelişen fizyolojik ve psikolojik tepkiler bütünüdür (Arıcan, 2011, s. 56). Stresin işle ilgili bölümünde rol belirsizliği, aşırı iş yükü gibi işten kaynaklanan faktörler sayılmasıyna ilaveten örgüt içi insan ilişkileri ve kişisel çatışmalar yoğun stresin öfkeye ve saldırganlığa neden olabilmektedir.

\section{LITERATÜR ÇALIŞMASI}

Yıldırım vd. tarafindan (2004) Modern Toplum Hastalığı: Stres ve Muhasebe Meslek Elemanı Üzerindeki Etkileri isimli çalışmalarında, çevresel faktörlerin meslek mensupları üzerinde daha fazla stres oluşturduğu ve katılımcıların \%65'inin stres kaynaklı baş ağrısı yaşadıkları sonuçlarına ulaşmışlardır.

Bekçi vd. (2007) Muhasebe Meslek Mensuplarında Stres Kaynağının Belirlenmesine Yönelik Bir Araştırma konulu çalışmalarını Isparta ve Burdur illerindeki meslek mensupları üzerine gerçekleştirmişlerdir. Meslek mensuplarının genelde stres altında olduklarını bildikleri, stresin iş yüklerine bağlı olarak ortaya çıktığı sonuçlarına ulaşılmıştır.

Koçyiğit vd.(2010) Muhasebe Meslek Mensuplarının Örgütsel Stres Kaynaklarını Belirlemeye Yönelik Bir Araştırma: Ankara İli Örneği isimli çalışmalarında, mükelleflerin muhasebe ücretlerini zamanında ödememesi, çalışma saatinin uzunluğu, İş yükünün ağır olması, mevzuatın karışık olması odanın belirlediği ücretlerin yetersizliği vb unsurların meslek mensupları üzerinde strese neden olduğu sonucuna ulaşmışlardır.

Özkan ve Özdevecioğlu (2011) Muhasebe meslek mensuplarının mesleki streslerinin ruhsal ve fiziksel sağlıkları üzerindeki etkileri konulu çalışmalarında mesleki stres ortalamanın üzerinde bulunmuştur. Yapılan analizlere göre, mesleki stres arttıkça muhasebe meslek mensuplarının fiziksel sağlıkları ve ruhsal sağlıklarının azaldığ 1 sonucuna ulaşılmıştır.

Kaplanoğlu (2014) Mesleki Stresin Temel Nedenleri ve Muhtemel Sonuçları: Manisa İlindeki SMMM'ler Üzerine Bir Araştırma isimli çalışmasında İşlerin giderek karmaşık bir hal almasının yoğun strese yol açtığı sonucuna ulaşılmıştır. Katılımcılar işlerinin sağlıklarını etkilediklerini ve gerilim altında çalıştıklarını ifade etmişlerdir.

Hacıhasanoğlu ve Karaca (2014) Bağımsız Çalışan Muhasebe Meslek Mensuplarının ve Muhasebe Çalışanlarının Tükenmişlik, İş Tatmini Ve Stres 
KAÜiiBFD 11(21), 2020: 203-224

Düzeylerinin Belirlenmesine Yönelik Bir Alan Araştırması gerçekleştirmişlerdir. İş tatmini düzeyi yüksek olmasına karşın, çalışanların aşırı stresli olduğu, stresteki artışın duygusal tükenmede ve duyarsızlaşmada artışa neden olduğu sonuçlarına ulaşılmıştır.

Uysal vd. (2015) Aşııı İş Yükünün Performans Perspektifinden Çalıma Psikolojisinde Negatifliğe Etkisi: Muhasebe Meslek Mensuplarına Yönelik Bir Araştırma gerçekleştirmişlerdir. Çalışmayı Zonguldak ilindeki 75 muhasebe meslek mensubuna uygulamışlardır. Çalışanlar üzerinde iş yükünün aşırı artması, çalışanların bu iş yükünün üstesinden gelse bile algısal olarak bu durumun psikolojilerine yerleşmesi, çalıma psikolojilerindeki negatifliği çok yüksek oranda etkilediği sonuçlarına ulaşmışlardır.

\section{STRES VE ÖFKE İLIŞKISINININ VERILERLE DEĞERLENDİRILMESİ}

\subsection{Araştırmanın Amacı ve Önemi}

$\mathrm{Bu}$ araştırmada muhasebe meslek mensuplarında stres ve öfke ilişkisinin belirlenmesi amaçlanmaktadır. Birinci olarak mesleğin çalışanlarının stres ve öfke düzeylerinin demografik verilerle ilişkisi, ikinci olarak ise stres ile öfke düzeylerinin karşılaştırılması yapılarak stres ve öfke arası ilişki açıklanmak istenmektedir.

\subsection{Araştırmanın Yöntemi ve Sınırlııkları}

Çalışmamız 2018 Aralık ayında yapılmıştır. Elazı̆̆ Serbest Muhasebeci ve Mali Müşavirler Odasında kayıtları bulunun 204 serbest muhasebeci ve mali müşavir bulunmaktadır. Çalışma kapsamında 26'sı henüz serbest muhasebeci ve mali müşavirlik belgesini almamış muhasebe meslek elemanı 54'ü serbest muhasebeci ve mali müşavir, olmak üzere 80 muhasebe meslek mensubu ile görüşülerek anket yöntemi uygulanmıştır. Araştırmanın evrenini, Elazı ̆̆ ilinde aktif faaliyet gösteren 204 muhasebe meslek mensubu oluşturmaktadır. Araştırmanın örneklemini ise tesadüfi olarak araştırmaya dahil edilen 80 muhasebe meslek mensubu oluşturmaktadır. Araştırmanın amacına en uygun örneklem hacminin belirlenmesi için Cochran formülü olarakta bilinen aşağıdaki formülden yararlanılmıştır(Gürbüz, \& Şahin, 2016).

$\mathrm{n}=(\mathrm{N}) \times(\mathrm{t} 2) \times(\mathrm{p} \times \mathrm{q}) /(\mathrm{d} 2) \times(\mathrm{N}-1)+(\mathrm{t} 2) \times(\mathrm{p} \times \mathrm{q})$,

n: Örneklem Hacmi (111),

N: Evren Hacmi (204),

t: Güvenilirlik düzeyine ait tablo değeri (1.96), 
p: İlgili olayın görülme olasılıkları (0.2),

q: İlgili olayın görülmeme olasılıkları (0.8),

d: Duyarlılık düzeyi (0.05)

Araştırmanın örneklem büyüklüğünün belirlemesi amaciyla Alpha değeri 0.05 ve $\% 5$ örneklem hatası ile $\mathrm{p}=0.2, \mathrm{q}=0.8, \mathrm{t}=1.96$ değeri alınıp hesaplandığında anakütleyi temsil edebilecek örneklem büyüklügünün yaklaşık olarak 111 bireyden oluşabileceği anlaşılmaktadır. Fakat araştırmaya dahil olan muhasebe meslek mensuplarına uygulanan anketler sonucunda eksik ve hatalı doldurulmuş olan 31 anket, değerlendirme dışı bırakılmış ve analizler 80 muhasebe meslek mensubunun katılımı ile elde edilen verilerden gerçekleştiği için araştırmanın örneklemi 80 olarak belirlenmiştir.

$\mathrm{Bu}$ araştırmada temelde nicel verilere dayalı araştırma ve ölçme yöntemi benimsenmiştir. Stres için meslek mensuplarının stres kaynaklarını belirlemeye yönelik olarak araştırmacılar (Kayıhan, 2015, s. 380) tarafindan geliştirilen 39 sorudan oluşmaktadır. Öfke ölçeği ise A. Kadir Özer tarafından yapılmış "Sürekli Öfke-Öfke Tarzı Ölçeği”" (SÖÖTÖ) ölçeği kullanılmıştır (Özer, 1994). Bu noktadan hareketle anket belirlenmesinde nicel verilere dayalı olan araştırma ve ölçme yöntemlerinin benimsendiği çalışmalarda yaygın olarak kullanılan Likert ölçeği model olarak kullanılmıştır. Anketler yüz yüze görüşme teknikleri uygulanarak doldurulmuş ve sonuçlar SPSS 22 programında değerlendirilmeye tabi tutulmuştur.

\subsection{Güvenirlilik Analizi}

Çalışmamızda Cronbach Alpha katsayısı stres ölçeğinin 0,92 öfke ölçeğinin 0,84 olarak gerçekleşmiştir. Bu rakam bize ölçeğin yeterli derecede güven arz ettiğini göstermektedir.

\subsection{Araștırmanın Analizi}

Araştırma analizi aşağıda sunacağımız tablolar ve bu tablolardaki sonuçların incelenmesi çerçevesinde gerçekleşecektir.

Araştırma kapsamında muhasebe meslek mensuplarının demografik bulgular yer almaktadır. Ayrıca bu başlıkta demografik bulgulara ilaveten demografik verilerle korku ortalamaları arasındaki ilişki varyans analizi kullanılarak verilmiştir. İki değişken arasındaki farklılıkların tespit edilmesi için Varyans analizi (ANOVA, Analysis Of Variance) kullanılmıştır. Varyans analizi (ANOVA, Analysis Of Variance) iki ya da daha fazla gruba ait ortalamalar arasındaki farkın anlamlı olup olmadığı ile ilgili hipotezleri test etmek için 
kullanılmaktadır. İki grubun ortalamaları arasındaki farkın anlamlı olup olmadığı t testi kullanılarak da incelenmiştir. İkiden fazla grubun ortalamaları karşılaştırılmasında ise F Testi diğer bir ismiyle Varyans Analizi (ANOVA, Analysis Of Variance) kullanılmıştır. İkiden fazla grubun ortalamaları arasında anlamlı bir farklılık olup olmadığını test eden $\mathrm{F}$ testinin ve $\mathrm{T}$ testinin hipotezi aşağıdaki gibidir.

alfa: 0,05 $\mathrm{p}<$ alfa ise anlamlı bir farkl1lık göstermektedir.

alfa:0,05 p>alfa ise anlamlı bir farklılık göstermemektedir

Tablo 1. Muhasebe Meslek Mensuplarının Cinsiyetine Göre Stres ve Öfkeye Maruz Kalma Durumları

\begin{tabular}{|l|l|l|l|l|l|l|l|}
\hline & Cinsiyet & Say1 & Ortalama & $\begin{array}{l}\text { Standart } \\
\text { sapma }\end{array}$ & F & S & t \\
\hline \multirow{3}{*}{ Stres } & Kadın & 20 & 3,17 &, 686 & \multirow{2}{*}{, 033} & \multirow{2}{*}{, 856} & 1,482 \\
\cline { 2 - 5 } & Erkek & 60 & 2,89 &, 737 & & 1,537 \\
\hline \multirow{2}{*}{ Öfke } & Kadın & 20 & 2,27 &, 449 & \multirow{2}{*}{, 136} & \multirow{2}{*}{, 713} &, 908 \\
\cline { 2 - 5 } & Erkek & 60 & 2,16 &, 468 &, 927 \\
\hline
\end{tabular}

Muhasebe meslek mensuplarının stres düzeyleri ile cinsiyet arasında ilişki yoktur. $(\mathrm{P}=0,85, \mathrm{P}>0,05)$

Muhasebe meslek mensuplarının öfke düzeyleri ile cinsiyet arasında ilişki yoktur. $(\mathrm{P}=0,71, \mathrm{P}>0,05)$

Cinsiyet esas alınarak yapılan incelemede, ortalamalar itibari ile stres ve öfke ortalamaları şu şekilde ortaya çıkmaktadır: Stres düzey, yüksekten aşağıya doğru sıralama yapıldığında kadınlar erkekler şeklinde gerçekleştiği görülmektedir. En fazla strese maruz kalan grup kadınlardır. Cinsiyet ile stres düzeyi $\mathrm{P}=0,85$ olduğundan muhasebe meslek mensuplarının stres düzeyleri ile cinsiyetleri arasında anlamlı bir ilişki yoktur. Öfke düzeyleri ve cinsiyet ilişkisine bakıldığında $\mathrm{P}=0,71$ olduğundan öfke düzeyi ile cinsiyet arasında ilişki bulunamamıştır. Kadın ve erkek muhasebe meslek mensuplarında öfke düzeyi arasında anlamlı bir farklılık olmadığı görülmektedir. Ancak stres düzeyi yüksek olan kadın meslek mensuplarının öfke düzeylerinin de yüksek olduğu görülmektedir. Kadın iş hayatında üstlendiği rolün dışında bir eş ve bir anne rolüne sahiptir. Ancak muhasebe mesleğinin yoruculuğu, zaman kavramının olmayışı gibi etkenler göz önünde bulundurulduğunda kadınların evlerine ve çocuklarına yeterli zamanı ayıramıyor olmaları stres ve öfkenin erkeklere göre 
daha yüksek çıkmasındaki en büyük etmendir.

Tablo 2. Muhasebe Meslek Mensuplarının Medeni Durumuna Göre Stres ve Öfkeye Maruz Kalma Durumları

\begin{tabular}{|c|c|c|c|c|c|c|}
\hline & Medeni Durum & $\begin{array}{l}\text { Sa } \\
\text { y1 }\end{array}$ & $\begin{array}{l}\text { Ortalam } \\
\text { a }\end{array}$ & $\begin{array}{l}\text { Standart } \\
\text { sapma }\end{array}$ & $\mathrm{F}$ & $\mathrm{p}$ \\
\hline \multirow{3}{*}{ Stres } & Evli & 52 & 3,07 & $\begin{array}{l}, 743 \\
\end{array}$ & \multirow{3}{*}{3,118} & \multirow{3}{*}{, 050} \\
\hline & Bekar & 25 & 2,83 & ,666 & & \\
\hline & Dul & 3 & 2,12 & ,229 & & \\
\hline \multirow{3}{*}{ Öfke } & Evli & 52 & 2,28 & ,428 & \multirow{3}{*}{2,883} & \multirow{3}{*}{, 062} \\
\hline & Bekar & 25 & 2,02 & 517 & & \\
\hline & Dul & 3 & 2,08 & ,147 & & \\
\hline
\end{tabular}

Muhasebe meslek mensuplarının stres düzeyleri ile medeni durumları arasında ilişki yoktur. $(\mathrm{P}=0,05, \mathrm{P}>0,05)$

Muhasebe meslek mensuplarının öfke düzeyleri ile medeni durumları arasında ilişki yoktur. $(\mathrm{P}=0,06, \mathrm{P}>0,05)$

Muhasebe meslek mensuplasının medeni durumları esas alınarak yapılan incelemede, boyutlar itibari ile stres ve öfke ortalamaları şu şekilde ortaya çıkmaktadır: Strese maruz kalmada yüksekten aşağıya doğru sıralama yapıldığında evlilerin 3,07 ile daha yüksek stres ortalamaya sahip olduğu görülmektedir. Öfke ortalamalarıda stres ortalamalarıla benzerlik göstermektedir. En yüksek ortalamaya sahip grup 2,28 ile evlilerdir.

Evli kişilerin sorumlulukları ve rollerinin daha karmaşı olması stres ve öfke düzeylerinin diğer gruplardan daha yüksek çıkmasına neden olduğu söylenebilir. Evliliğin işle ilgili tetikleyicilere sahip olması işin ise sorumluluk yükünden kaynaklı olarak daha stres oluşturması evlilerde stres ve öfke düzeyinin yükselmesine neden olmaktadır. 
Tablo 3. Muhasebe Meslek Mensuplarının Yaş Durumuna Göre Stres ve Öfkeye Maruz Kalma Durumları

\begin{tabular}{|c|c|c|c|c|c|c|}
\hline & Yaş & Say1 & Ortalama & Standart sapma & $\mathrm{F}$ & $p$ \\
\hline \multirow{5}{*}{ Stres } & 30 ve alt1 & 19 & 2,96 & 493 & \multirow{5}{*}{1,824} & \multirow{5}{*}{,133 } \\
\hline & $31-40$ & 29 & 2,83 & ,764 & & \\
\hline & $41-50$ & 15 & 2,76 & ,759 & & \\
\hline & $51-60$ & 15 & 3,31 & 825 & & \\
\hline & 61 ve üzeri & 2 & 3,58 & ,159 & & \\
\hline \multirow{5}{*}{ Öfke } & 30 ve alt1 & 19 & 2,06 & ,364 & \multirow{5}{*}{1,170} & \multirow{5}{*}{,331 } \\
\hline & $31-40$ & 29 & 2,21 & ,453 & & \\
\hline & $41-50$ & 15 & 2,09 & 502 & & \\
\hline & $51-60$ & 15 & 2,35 &, 529 & & \\
\hline & 61 ve üzeri & 2 & 2,45 & ,640 & & \\
\hline
\end{tabular}

Muhasebe meslek mensuplarının stres düzeyleri ile yaş arasında ilişki yoktur. $(\mathrm{P}=0,133, \mathrm{P}>0,05)$

Muhasebe meslek mensuplarının öfke düzeyleri ile yaş arasında ilişki yoktur. $(\mathrm{P}=0,331, \mathrm{P}>0,05)$

Muhasebe meslek mensuplarının yaşları esas alınarak yapılan incelemede, ortalamalar itibari ile stres ve öfke ortalamaları şu şekilde ortaya çıkmaktadır: Stres düzeyi en yüksek grup 3,31 ortalamayla 61 ve üzeri yaş grubudur. Onu bir alt grup olan 51-60 yaş grubu izlemektedir. Öfke ortalamaları stres ortalamaları ile benzerlik göstermektedir. Yaşın vermiş olduğu yorgunluk tahammülsüzlük durumuna yol açtığından ve mesleğin yıllar içerisinde teknolojinin gelişmesiyle birlikte geçirdiği değişimin sürekli takip edilme zorunluluğu göz önünde bulundurulduğunda bu yaş grubundaki bireylerin stres ve öfke düzeyinin yüksek olmasına neden olduğu söylenebilir. 
Tablo 4. Muhasebe Meslek Mensuplarının Eğitim Durumuna Göre Stres ve Öfkeye Maruz Kalma Durumları

\begin{tabular}{|c|c|c|c|c|c|c|}
\hline & & Say1 & Ortalama & $\begin{array}{l}\text { Standart } \\
\text { sapma }\end{array}$ & $\mathrm{F}$ & $\mathrm{p}$ \\
\hline \multirow{5}{*}{ Stres } & Lise & 7 & 3,55 &, 534 & \multirow{5}{*}{1,679} & \multirow{5}{*}{, 164} \\
\hline & Önlisans & 21 & 2,96 &, 780 & & \\
\hline & Lisans & 44 & 2,83 &, 742 & & \\
\hline & Yükseklisans & 7 & 3,07 &, 433 & & \\
\hline & Doktora & 1 & 3,42 & . & & \\
\hline \multirow{5}{*}{ Öfke } & Lise & 7 & 2,53 & ,358 & \multirow{5}{*}{2,861} & \multirow{5}{*}{,029 } \\
\hline & Önlisans & 21 & 2,28 &, 516 & & \\
\hline & Lisans & 44 & 2,09 & ,392 & & \\
\hline & Yükseklisans & 7 & 2,04 &, 580 & & \\
\hline & Doktora & 1 & 3,03 & & & \\
\hline
\end{tabular}

Muhasebe meslek mensuplarının stres düzeyleri ile eğitim durumu arasında ilişki yoktur. $(\mathrm{P}=0,164, \mathrm{P}>0,05)$

Muhasebe meslek mensuplarının öfke düzeyleri ile eğitim durumu arasında ilişki vardır. $(\mathrm{P}=0,029, \mathrm{P}<0,05)$

Muhasebe meslek mensuplarının eğitim durumları esas alınarak yapılan incelemede, stres ve öfke ortalamaları şu şekilde ortaya çıkmaktadır: Stres ve öfke ortalamaları paralellik göstermektedir. yüksek ortalamaya sahip olan gruplar 3,55 ile lise 3,42 ile doktora mezunlarında görülmektedir. Beklenti ve korku faktörüyle açıklanabilecek stres ve öfke ortalamaları doktora mezunu olanların beklentileri ile uyuşmayan ücret eşitsizlikleri, adaletsizlik algıs1, yükselme olanaklarının zorluğu ile açıklanırken lise düzeyi grubunun ise yetenek yitimi, işsizlik, gelecek belirsizliği, plansız yaşam olarak sıralanabilir. Özellikle öfke düzeyinin eğitim durumuyla arasındaki ilişkide bu minvalde açıklanabilir. 
Tablo 5. Muhasebe Meslek Mensuplarının Çalışma Şekline Göre Stres ve Öfkeye Maruz Kalma Durumları

\begin{tabular}{|c|c|c|c|c|c|c|}
\hline & & Say1 & $\begin{array}{l}\text { Ortala } \\
\text { ma }\end{array}$ & $\begin{array}{l}\text { Standart } \\
\text { sapma }\end{array}$ & $\mathrm{F}$ & $\mathrm{p}$ \\
\hline \multirow{3}{*}{ Stres } & Bağımsız & 43 & 3,04 & ,764 & \multirow{3}{*}{ 955 } & \multirow{3}{*}{,389 } \\
\hline & $\begin{array}{l}\text { Kamu-özel firmaya } \\
\text { bağl1 }\end{array}$ & 11 & 3,01 &, 721 & & \\
\hline & $\begin{array}{l}\text { Bir muhasebecinin } \\
\text { yanında }\end{array}$ & 26 & 2,80 & 674 & & \\
\hline \multirow{3}{*}{ Öfke } & Bağımsız & 43 & 2,24 & ,462 & \multirow{3}{*}{1,465} & \multirow{3}{*}{,237 } \\
\hline & $\begin{array}{l}\text { Kamu-özel } \\
\text { firmaya bağl1 }\end{array}$ & 11 & 2,26 & ,507 & & \\
\hline & $\begin{array}{l}\text { Bir muhasebecinin } \\
\text { yanında }\end{array}$ & 26 & 2,06 & ,438 & & \\
\hline
\end{tabular}

Muhasebe meslek mensuplarının stres düzeyleri ile çalışma şekli arasında ilişki yoktur. $(\mathrm{P}=0,389, \mathrm{P}>0,05)$

Muhasebe meslek mensuplarının öfke düzeyleri ile çalışma şekli arasında ilişki yoktur. $(\mathrm{P}=0,237, \mathrm{P}>0,05)$

Muhasebe meslek mensuplarının çalışma şekli esas alınarak yapılan incelemede, stres ve öfke ortalamaları şu şekilde ortaya çıkmaktadır: Çalışma şekline göre stres ve öfke ortalamalarında benzerlik görülebilmektedir. Bağımsızlardan oluşan grubun stres ortalaması 3,04,kamu-özel firmaya bağlı grubun ortalaması ise 3,01; öfkede ise kamu-özel firmaya bağlı grubun 2,26, bağımsızlardan oluşan grubun 2,24'tür. Kamuya-özel firmaya bağlı olan grubun stres ve öfke ortalamalarında örgütsel stres ve öfke kaynakları etkili olduğu söylenebilir. Örgüt içi fiziksel şartlardan kaynaklanan kalabalık çalışma ortamları, havalandırma ve aydınlatma yetersizlikleri, gürültü, yetersiz iletişim, mobing, yetersiz bilgi, adaletsizlik algısı, örgütsel kuralların katılığı, ücret eşitsizliği, rol belirsizliği, yüksek derecede uzmanlaşma sayılabilir. Bağımsız çalışanlarda ise mükelleflerle ilişkilerindeki olumsuz durumlar stres ve öfke artırıcı olarak görülebilir. 
Tablo 6. Muhasebe Meslek Mensuplarının Mesleki Tecrübesine Göre Stres ve Öfkeye Maruz Kalma Durumları

\begin{tabular}{|c|c|c|c|c|c|c|}
\hline & $\begin{array}{l}\text { Mesleki } \\
\text { Tecrübe }\end{array}$ & Say1 & Ortalama & $\begin{array}{l}\text { Standart } \\
\text { sapma }\end{array}$ & $\mathrm{F}$ & $\mathrm{p}$ \\
\hline \multirow{6}{*}{ Stres } & 5 y1l ve alt1 & 17 & 3,01 &, 532 & \multirow{6}{*}{2,543} & \multirow{6}{*}{,035 } \\
\hline & 6 ve 10 y1l & 24 & 2,84 & ,668 & & \\
\hline & 11 ve 15 y1l & 10 & 2,45 & 930 & & \\
\hline & 16 ve 20 y1l & 15 & 2,98 & ,767 & & \\
\hline & 21 ve 25 y1l & 10 & 3,47 & ,722 & & \\
\hline & 26 yıl ve üzeri & 4 & 3,34 & ,384 & & \\
\hline \multirow{6}{*}{ Öfke } & 5 y1l ve alt1 & 17 & 2,09 & ,363 & \multirow{6}{*}{,809 } & \multirow{6}{*}{, 547} \\
\hline & 6 ve 10 yil & 24 & 2,19 & 399 & & \\
\hline & 11 ve 15 y1l & 10 & 2,06 &, 471 & & \\
\hline & 16 ve 20 y1l & 15 & 2,25 & ,608 & & \\
\hline & 21 ve 25 y1l & 10 & 2,41 &, 418 & & \\
\hline & 26 yil ve üzeri & 4 & 2,14 & 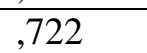 & & \\
\hline
\end{tabular}

Muhasebe meslek mensuplarının stres düzeyleri ile mesleki tecrübe arasında iliş̧ki yoktur. $(\mathrm{P}=0,035, \mathrm{P}>0,05)$

Muhasebe meslek mensuplarının stres düzeyleri ile mesleki tecrübe arasında ilişki yoktur. $(\mathrm{P}=0,547, \mathrm{P}>0,05)$

Muhasebe meslek mensuplarının mesleki tecrübeleri esas alınarak yapılan incelemede, stres ve öfke ortalamaları şu şekilde ortaya çıkmaktadır: Stres düzeyi en yüksek grup 3,47 ortalamayla 21-25 yıl arası mesleki deneyimi olanlardır. Onu bir alt grup olan 26 yıl ve üzeri mesleki deneyimi olanların bulunduğu grup izlemektedir. Öfke ortalamaları stres ortalamaları ile benzerlik göstermektedir. Tablo 3'teki ortalamalarla benzerlik gösteren mesleki tecrübe yaş arttıkça tahammülsüzlüğün oluşması ve eylemlerin, durumların sonuçlarını öngörebilme becerisi kazanmış olmak risk değerlendirmelerini daha iyi yapmaya ve buna bağlı olarak stres ve öfkeye neden olduğu söylenebilir. Öngörü arttıkça sonuç hakkında gerçekçi tahminler artmakta bazen müdahale olanağının olmaması ise öfke ve strese neden olabilmektedir. 5 yıl ve altı grunun öfke ve stres ortalamalarının diğer gruplara göre yüksek olmasının sebebi ise gelecek öngörüsünün olmamas1 ve belirsizliklerin olduğu söylenebilir. 
KAÜiIBFD 11(21), 2020: 203-224

Tablo 7. Muhasebe Meslek Mensuplarının Unvanına Göre Stres ve Öfkeye Maruz Kalma Durumları

\begin{tabular}{|l|l|l|l|l|l|l|}
\hline & Unvan & Say1 & Ortalama & $\begin{array}{l}\text { Standart } \\
\text { sapma }\end{array}$ & F & p \\
\hline \multirow{2}{*}{ Stres } & MME & 26 & 2,98 &, 597 & & \multirow{2}{*}{, 384} \\
\cline { 2 - 6 } & SMMM & 54 & 2,93 &, 786 &, 970 &, 46 \\
\hline \multirow{2}{*}{ Öfke } & MME & 26 & 2,09 &, 442 & \multirow{2}{*}{, 904} &, 409 \\
\cline { 2 - 6 } & SMMM & 54 & 2,23 &, 474 & \multicolumn{2}{|c|}{} \\
\hline
\end{tabular}

Muhasebe meslek mensuplarının stres düzeyleri ile unvan arasında ilişki yoktur. $(\mathrm{P}=0,384, \mathrm{P}>0,05)$

Muhasebe meslek mensuplarının stres düzeyleri ile unvan arasında ilişki yoktur. $(\mathrm{P}=0,409, \mathrm{P}>0,05)$

Muhasebe meslek mensuplarının unvanları esas alınarak yapılan incelemede, stres ve öfke ortalamaları şu şekilde ortaya çıkmaktadır: Stres düzeyi en yüksek grup 2,98 ortalamayla muhasebe meslek mensuplarıdır. Öfke düzeyi en yüksek grup ise 2,23 ortalamayla serbest muhasebeci ve mali müşavirlerdir. Öfke ve stres düzeyinin gruplar arası farklılık göstermesini şöyle açıklayabiliriz. Muhasebe meslek mensupları henüz mali müşavirlik belgesini almamış serbest muhasebeci ve mali müşavirin yanında çalışan kişilerden oluştuğu için ücret kaygısı, işini kaybetme korkusu, gibi sebeplerden ötürü stres düzeyleri yüksektir. Serbest Muhasebeci ve Mali Müşavirler ise kendi adına bağımsız iş yeri olan gerek mükelleflerle, gerekse resmi kurumlarla olan ilişkilerde sorumlu durumda olan ve bu sorumluluğun ağır iş yükü, mükeleflerin uygun olmayan talepleri ve bu taleplerle mevzuat arasında kalınması gibi nedenlerden ötürü öfkeye sebebiyet verdiği düşünülmektedir. 
Tablo 8. Muhasebe Meslek Mensuplarının Gelirine Göre Stres ve Öfkeye Maruz Kalma Durumları

\begin{tabular}{|c|c|c|c|c|c|c|}
\hline & Aylık Gelir & Say1 & Ortalama & $\begin{array}{l}\text { Standart } \\
\text { sapma }\end{array}$ & $F$ & $\mathrm{p}$ \\
\hline \multirow{6}{*}{ Stres } & $\begin{array}{ll}1000 & \text { TL'den } \\
\text { az } & \end{array}$ & 3 & 3,68 & 251 & \multirow{6}{*}{4,725} & \multirow{6}{*}{, 001} \\
\hline & $1001-2000$ & 11 & 2,92 & ,769 & & \\
\hline & $2001-3000$ & 11 & 2,81 &, 581 & & \\
\hline & $3001-4000$ & 9 & 3,01 & ,601 & & \\
\hline & $4001-5000$ & 11 & 2,19 &, 489 & & \\
\hline & $\begin{array}{lll}5001 & \text { TL } & \text { ve } \\
\text { üzeri } & & \\
\end{array}$ & 35 & 3,19 & ,711 & & \\
\hline \multirow{6}{*}{ Öfke } & $\begin{array}{ll}1000 & \text { TL'den } \\
\text { az } & \\
\end{array}$ & 3 & 2,12 & ,298 & \multirow{6}{*}{, 827} & \multirow{6}{*}{, 534} \\
\hline & $1001-2000$ & 11 & 1,95 &, 557 & & \\
\hline & $2001-3000$ & 11 & 2,17 & 288 & & \\
\hline & $3001-4000$ & 9 & 2,34 & ,343 & & \\
\hline & $4001-5000$ & 11 & 2,23 & 423 & & \\
\hline & $\begin{array}{lll}5001 & \text { TL } & \text { ve } \\
\text { üzeri } & & \\
\end{array}$ & 35 & 2,22 &, 521 & & \\
\hline
\end{tabular}

Muhasebe meslek mensuplarının stres düzeyleri ile gelir düzeyi arasında ilişki vardir. $(\mathrm{P}=0,001, \mathrm{P}<0,05)$

Muhasebe meslek mensuplarının stres düzeyleri ile yaş arasında ilişki yoktur. $(\mathrm{P}=0,534, \mathrm{P}>0,05)$

Muhasebe meslek mensuplarının gelir düzeyi esas alınarak yapılan incelemede, stres ve öfke ortalamaları şu şekilde ortaya çıkmaktadır: stres ortalaması en yüksek grup 3,68 ile 1000 Tl'den az kazananlardır. Bu grubun özellikle günümüz şartlarında bu gelir ile kişisel ihtiyaçlarını karşılamaktan yoksun olması, yapılan iş ile ücret arasındaki dengesizlik bu bireylerin gelecek için plan yapmasını engellemektedir. Geleceği plansız yaşayan bireylerin Türkiye kültürü çerçevesinde değerlendirildiğinde toplumun maddi ve manevi beklentilerini karşılayamama sonucu stres düzeyinin yüksek olduğı söylenebilir. Ebeveynelere muhtaç olmadan kendi ihtiyaçlarını karşılama, evlilik ve çocuk, ev ve araba beklentisine karşın $1000 \mathrm{Tl}$ altı ücretin kazanıliyor olması yoğun strese neden olabilmektedir. Aynı nedenlerin aynı grup üzerinde doğal olarak öfke

\section{8}


ortalamalarındaki artışa neden olduğu söylenebilir. 5001 Tl'den yüksek kazanan grubun stres ve öfke ortalamarındaki yükseklik ise planlı yaşama ilaveten büyüme amacı, yapılan yatırımlar ve harcamadaki artış stres ve öfke ortalamalarını artırdığı söylenebilir.

\subsection{Muhasebe Meslek Mensuplarının Stres ve Öfke Korelasyon Analizi}

İki sayısal ölçüm arasında doğrusal bir ilişki olup olmadığını, varsa bu ilişkinin yönünü ve şiddetinin ne olduğunu belirlemek için kullanılan bir istatistiksel yöntemdir. Verilerin normal dağılıma sahip olması durumunda Pearson korelasyon katsayısı, verilerin normal dağılmadığı durumda ise Spearman Rank korelasyon katsayıs1 tercih edilir. Bir korelasyon katsayısının yorumlanabilmesi için $\mathrm{p}$ değerinin 0.05 den daha küçük olması gerekir. Korelasyon katsayısı negatif ise iki değişken arasında ters ilişki vardır, yani "değişkenlerden biri artarken diğeri azalmaktadır" denir. Korelasyon katsayısı pozitif ise "değişkenlerden biri artarken diğeri de artmaktadır" yorumu yapılır. Korelasyon katsayısı (r) nın yorumu;

$\mathrm{r}<0.2$ ise çok zayıf ilişki yada korelasyon yok

0.2-0.4 arasında ise zayıf korelasyon

0.4-0.6 arasında ise orta şiddette korelasyon

0.6-0.8 arasında ise yüksek korelasyon

$0.8>\mathrm{r}$ ise çok yüksek korelasyon olduğu yorumu yapılır. 
Tablo 9. Muhasebe Meslek Mensuplarının Stres ve Sürekli Öfke İlişkisi

\begin{tabular}{|l|l|l|l|}
\hline & & Stres & Sürekli Öfke \\
\hline Stres & $\begin{array}{l}\text { Pearson } \\
\text { Correlation }\end{array}$ & 1 &, $417^{* *}$ \\
\cline { 2 - 4 } & Sig. (2-tailed) & &, 000 \\
\cline { 2 - 4 } & N & 80 & 80 \\
\hline Sürekli Öfke & $\begin{array}{l}\text { Pearson } \\
\text { Correlation }\end{array}$ &, $417^{* *}$ & 1 \\
\cline { 2 - 4 } & Sig. (2-tailed) &, 000 & \\
\cline { 2 - 4 } & N & 80 & 80 \\
\hline
\end{tabular}

**. Correlation is significant at the 0.01 level (2-tailed).

Tabloya göre muhasebe meslek mensuplarının stres ile sürekli öfke arasında orta derecede bir ilişki vardır. $(\mathrm{R}=-0,417)$. Sürekli öfke düzeyinin yoğunluğu ile ilgili soruları içermektedir. Öfke ve stres aynı ortamlarda oluştuğundan birbiri ile ilişkisinin olması beklenen bir sonuçtur. Fakat muhasebe mesleğinin insaninsan ilişkisini içermesi, düzenlemelerle mesleğin dinamik oluşu stres ve öfke düzeyini artırmaktadır.

Tablo 10. Muhasebe Meslek Mensuplarının Stres ve Öfke İçte İlişkisi

\begin{tabular}{|l|l|l|l|}
\hline & & Stres & Öfke İçte \\
\hline \multirow{4}{*}{ Stres } & $\begin{array}{l}\text { Pearson } \\
\text { Correlation }\end{array}$ & 1 &, $286^{* *}$ \\
\cline { 2 - 4 } & Sig. (2-tailed) & &, 010 \\
\cline { 2 - 4 } & N & 80 & 80 \\
\hline \multirow{2}{*}{ Öfke İçte } & $\begin{array}{l}\text { Pearson } \\
\text { Correlation }\end{array}$ &, $286^{* *}$ & 1 \\
\cline { 2 - 4 } & Sig. (2-tailed) &, 010 & 80 \\
\cline { 2 - 4 } & N & 80 & 8 \\
\hline
\end{tabular}

**. Correlation is significant at the 0.01 level (2-tailed).

Tabloya göre muhasebe meslek mensuplarının stres ile öfke içte arasında zayıf derecede bir ilişki vardır. $(\mathrm{R}=-0,286)$. Öfkenin bastırılmışlı̆̆ 1 olarak değerlendirilen öfke içte maddeleri ile stres arasında zayıf derecede de olsa ilişki bulunmuştur. Mesleğin mükelleflerle ilişkisi düşünüldüğünde öfkenin içe atılması müşteri kazanımı için önemli bir ketleyicidir. 
KAÜiIBFD 11(21), 2020: 203-224

Tablo 11. Muhasebe Meslek Mensuplarının Stres ve Öfke Dışa İlişkisi

\begin{tabular}{|l|l|l|l|}
\hline & & Stres & Öfke Dişa \\
\hline Stres & $\begin{array}{l}\text { Pearson } \\
\text { Correlation }\end{array}$ & 1 &, $324 * *$ \\
\cline { 2 - 4 } & Sig. (2-tailed) & &, 003 \\
\cline { 2 - 4 } & $\mathrm{N}$ & 80 & 80 \\
\hline \multirow{3}{*}{ Öfke Dişa } & $\begin{array}{l}\text { Pearson } \\
\text { Correlation }\end{array}$ &, $324^{* *}$ & 1 \\
\cline { 2 - 4 } & Sig. (2-tailed) &, 003 & \\
\cline { 2 - 4 } & $\mathrm{N}$ & 80 & 80 \\
\hline
\end{tabular}

**. Correlation is significant at the 0.01 level (2-tailed).

Tabloya göre muhasebe meslek mensuplarının stres ile öfkenin dışa yansıması arasında zayıf derecede bir ilişki vardır. $(R=-0,324)$. Öfkenin kolayca ifade ediliyor olması anlamına gelen öfke dışa maddeleri öfke içe maddelerinden daha yüksek bir etkiye sahiptir. Kültürel olarak öfkeyi yansitma şekli bu sonucu çıkardığı söylenebilir.

Tablo 12. Muhasebe Meslek Mensuplarının Stres ve Öfke Kontrol İlişkisi

\begin{tabular}{|l|l|l|l|}
\hline \multirow{4}{*}{ Stres } & & Stres & Öfke Kontrol \\
\hline \multirow{4}{*}{ Öfke Kontrol } & Pearson Correlation & 1 &, 093 \\
\cline { 2 - 4 } & Sig. (2-tailed) & &, 410 \\
\cline { 2 - 4 } & N & 80 & 80 \\
\cline { 2 - 4 } & Pearson Correlation &, 093 & 1 \\
\cline { 2 - 4 } & Sig. (2-tailed) &, 410 & \\
\cline { 2 - 4 } & $\mathrm{N}$ & 80 & 80 \\
\hline
\end{tabular}

Tabloya göre muhasebe meslek mensuplarının stres ile öfkenin dışa yansıması arasında bir ilişki yoktur. $(\mathrm{R}=-0,093)$. Öfkenin kontrol edilebildiğini gösteren öfke maddeleri ile stres arasında ilişki bulunamamıştır. Yani stres arttıkça meslek mensupları öfkelerini kontrol edememektedir. Bunun birinci sebebi öfkenin yansıtılmasını engelleyen kültürel değerlerin ve cezalandırılma şekillerinin ya yeterince güçlü olamayışı ya da yok oluşudur. Modernleşme ile ilişkisi düşünüldüğünde bireyselliğin artan etkisi öfkeyi gizlemeyi veya öfkeyi kontrol etmeyi zayıflatmaktadır. Küresel ekonomik sistem gelecekle ilgili planlı yaşama düşüncesini zayıflatarak geleceği belirsiz kılmaktadır. Bundan kaynaklı olarak öfke tetikleyicilerine daha açık olan kişi insanlar arası iletişim ağlarının menfaat üzerine kurulması sonucunda ise öfkeyi yansıtmakta kendisini durduracak herhangi bir ketleyici bulamamaktadır. 


\section{SONUÇ VE ÖNERILER}

Yapılan analizler sonucunda kadın meslek mensuplarının öfke ve stres düzeyinin erkek meslek mensuplarına göre daha yüksek olduğu tespit edilmiştir. Bunun temel nedenlerinden biri kadının iş hayatında üstlendiği rolün dışında bir eş ve bir anne rolüne sahip olmasıdır. Muhasebe meslek mensuplarının stres düzeyleri ile gelir düzeyi arasında ilişki bulunmaktadır. Gelir düzeyinin günümüz şartlarının altında olması meslek mensuplarının stres yaşamasına sebep olan en temel etmendir. Yapılan korelasyon analizlerinde ise, muhasebe meslek mensuplarının stres ile sürekli öfke arasında orta derecede bir ilişki bulunmuştur. Bunun nedeni mesleğin sürekli insan ilişkisine dayalı ve dinamik oluşu ile açıklanabilir. Muhasebe meslek mensuplarının stres ile öfkenin dışa yansıması arasında ise bir ilişki bulunamamıştır. Yani stres arttıkça meslek mensupları öfkelerini kontrol edememektedir.

Genel olarak muhasebe meslek mensupları mesleklerini icra ederken mükellef ve mevzuat, arasında sıkışıp kalmakta, ücretlerini tahsil ederken yaşanan güçlükler, haksız rekabet, meslek itibarının düşme tehlikesi, meslek mensubu sayısındaki hızlı artış, meslek odalarının sorunları çözmede yetersiz kalması, ara eleman sıkıntısı gibi nedenlerden dolayı zorluklar yaşamaktadırlar. Bu zorluklar meslek mensubu üzerinde stres ve öfkeye sebep olmaktadır. Stres meslek mensuplarının fiziksel ve psikolojik sağlığını da olumsuz etkilemektedir. Periyodik sürelerle evrakların GIBB ,SGK ve diğer Kamu kurumlarına zamanla yarış halinde süreli verilmeye çalışılması ve özellikle beyanname dönemlerinde ofislerdeki uzun çalışma saatleri sağlık alanında kendilerini ihmal etmelerine neden olmaktadır. Ayrıca yeni çıkan her belge verme ve düzenleme yükümlülüğü meslek mensuplarına yüklenmekte bu durum var olan iş yüklerine yük eklemektedir. En son yüklenen görevlerden biri olan geri kazanım katılım payı beyannamesini (poşet beyannamesi) örnek olarak verebiliriz. SM, SMMM ve YMM Çalışma Usul ve Esasları Yönetmeliği'nin ilgili maddesine göre, "meslek mensupları, mesleki dayanışma sorumluluğunun bilincinde olarak, haksız rekabete neden olacak durum ve davranışlardan kaçınırlar. Meslek mensupları, başka bir meslek mensubu ile mesleki sözleşmesi devam eden gerçek ve tüzel kişilere mesleki hizmet vermeye girişemezler. Aynı şekilde ücret ve eleman temini gibi konularda meslek mensupları birbirlerine zarar verecek davranışlarda bulunamazlar" ifadesi yer almaktadır (Serbest Muhasebeci, Serbest Muhasebeci Mali Müşavir Ve Yeminli Mali Müşavirlerin Çalışma Usul Ve Esasları Hakkında Yönetmelik,1990: Madde 10). Buna 
rağmen meslek mensuplarının en çok bu konudan dolayı muzdarip olduğunu söyleyebiliriz. Tüm bu saydığımız sebepler meslek mensuplarının stresli ve öfkeli biri olarak adlandırılması için yeterlidir. Bu konuda yapılması gerekenleri şöyle özetleyebiliriz. Türkiye Serbest Muhasebeci Mali Müşavirler ve Yeminli Mali Müşavirler Odaları Birliği (TÜRMOB ) tarafından haksız rekabeti önlemek amacıyla mükellefle yapılan sözleşmenin e birlik sistemine yüklenmesi sağlanmıştır. Ancak mevcut sistem haksız rekabetin önüne geçememiştir. Meslek mensuplarının mükellefle yaptığı sözleşmede belirttiği tutar ile aldıkları ücret arasında farklılıklar olduğu belirtilmiştir. Muhasebe ücretlerinin mükelleflerden Maliye Bakanlığınca tahsil edilerek meslek mensupların hesapların aktarılmasının bu konudaki sorunu çözeceğini düşünmekteyiz. Stres ve öfke konularında uzman kişilerce muhasebe meslek mensuplarına bilgi vermek amaciyla konferanslar düzenlenmelidir. Muhasebeciliğin çok dikkat isteyen ve hata kabul etmeyen bir meslek olduğu düşünüldügünde iş yükünün azaltılması gerekmektedir. Ofislerdeki uzun çalışma süreleri kısıtlanarak aileye daha fazla zaman ayırmalarının önü açılmalıdır.

$\mathrm{Bu}$ çalışma sadece Elazığ ilindeki meslek mensuplarını kapsamaktadır. Ancak diğer illerde de benzer çalışmaların yapılacak olması bu konuya dikkat çekmek açısından büyük önem taşımaktadır.

\section{KAYNAKÇA}

Arıcan K. (2011). Örgütsel Stres Kaynakları: Kavramsal Bir Çözümleme, Eğitim ve İnsani Bilimler Dergisi, 2(4), 55-76.

Altan, T. T., \& Çivitçi, A. (2017). Öfke ve Yaşam Doyumu Arasındaki İlişkide Affetmenin Düzenleyici Rolü, Mehmet Akif Ersoy Üniversitesi Sosyal Bilimler Enstitüsü Dergisi, 9(18), 308-327.

Bekçi, İ., Ömürbek, V., \& Tekşen, Ö. (2007). Muhasebe Meslek Mensuplarında Stres Kaynağının Belirlenmesine Yönelik, Süleyman Demirel Üniversitesi İktisadi ve İdari Bilimler Dergisi, 12(1), 145-161.

Goleman D. (2018). Duygusal Zeka Neden IQ'dan Daha Önemlidir. (çev.) Banu Seçkin Yüksel, İstanbul:Varlık

Gönen A. Ç. (2015). Öldürme Suçu İşlemiş Kadın ve Erkek Hükümlülerde Suç Motivasyonu ve Suça Etki Eden Faktörler. Yayımlanmamış Doktora Tezi, İstanbul Üniversitesi.

Gürbüz, S. \& Şahin, F. (2016). Sosyal Bilimlerde Araştırma Yöntemleri, Ankara Seçkin Yayıncılık. 
Hacıhasanoğlu, T., \& Karaca, N. (2014). Bağımsız Çalışan Muhasebe Meslek Mensuplarının ve Muhasebe Çalışanlarının Tükenmişlik, İş Tatmini Ve Stres Düzeylerinin Belirlenmesine Yönelik Bir Alan Araştırması, 19(4), 153-170.

Kaplanoğlu E. (2014). Mesleki Stresin Temel Nedenleri Ve Muhtemel Sonuçları: Manisa İlindeki SMMM'ler Üzerine Bir Araştırma, Muhasebe ve Finansman Dergisi, 64, 131-150.

Kayıhan, B., Tepeli, Y., Heybeli, B., \& Bakan, H. (2015). Muhasebe Meslek Mensuplarında Strese Neden Olan Faktörlerle İş Tatmin Düzeyleri Arasındaki İlişkinin Analizi: Muğla İli Örneği, Akademik Sosyal Araştırmalar Dergisi, 3(14), 374-390.

Keskin, G., Gümüş, A. B., \& Engin, E. (2011). Bir Grup Sağlık Çalışanında Öfke ve Mizaç Özellikleri: İlişkisel Bir İnceleme. Düşünen Adam Psikiyatri ve Nörolojik Bilimler Dergisi, 24, 99-208.

Koçyiğit Çil, S., Çına Bal, E., \& Öztürk, V. (2010) Muhasebe Meslek Mensuplarının Örgütsel Stres Kaynaklarını Belirlemeye Yönelik Bir Araştırma: Ankara İli Örneği, Eskişehir Osmangazi Üniversitesi, Sosyal Bilimler Dergisi, 11(1), 253-275.

Özer, A. K. (1994). Sürekli Öfke (SL-Öfke) ve Öfke İfade Tarzı (Öfke-Tarz) Ölçekleri Ön Çalışması. Türk Psikoloji Dergisi, 31, 26-35.

Özkan, A., \& Özdevecioğlu, M. (2011) Muhasebe Meslek Mensuplarının Mesleki Streslerinin Ruhsal Ve Fiziksel Sağlıkları Üzerindeki Etkileri, World Of Accounting Science, 13(3).

Tutar, H. (2014). Örgütsel Psikoloji: Endüstri ve Örgüt Psikolojisine Yeni Yaklaşımlar. Ankara:Detay

Uysal,T.. Akbulut, H., \& Ertan, S. (2015). Aşırı İş Yükünün Performans Perspektifinden Çalıma Psikolojisinde Negatifliğe Etkisi: Muhasebe Meslek Mensuplarına Yönelik Bir Araştırma, Uluslararası Sosyal Araştırmalar Dergisi, 8(38), 942-960.

Yıldırım, O,. Tektüfekçi, F., \& Çukacı. Y C. (2004). Modern Toplum Hastalığı: Stres ve Muhasebe Meslek Elemanı Üzerindeki Etkileri, Süleyman Demirel Üniversitesi İktisadi ve İdari Bilimler Fakültesi Dergisi, 9(2), $1-20$. 